\title{
Sonographic Evaluation of Obstetric Anal Injuries
}

\author{
${ }^{1}$ Themos Grigoriadis, ${ }^{2}$ Sylvia-Christina Mylona, ${ }^{3}$ George Giannoulis, ${ }^{4}$ Stavros Athanasiou, ${ }^{5}$ Aris Antsaklis
}

\begin{abstract}
Intrapartum damage to the anal sphincter is an important factor in fecal incontinence. Obstetric anal sphincter injuries (OASIS) vary from 1 to $18 \%$ of vaginal deliveries, including instrumental deliveries. The severity of anal sphincter injuries vary from superficial lacerations to deep injuries that can extend to the epithelium. Obstetric anal sphincter injuries are associated with both short-term complications (heavy bleeding, difficulties in recovery, increased incidence of infections, increased perineal pain) and long-term complications (rectovaginal fistulae or facal incontinence). A significant number of these anal sphincter injuries can be detected promptly after a good clinical examination, but still that does not exclude the possibility of these women suffering long-term complications. What is more when some of these so called 'occult tears' go undetected further increase the morbidity of the woman. Sonography of the perineum and the anal sphincter appears to offer a better diagnosis and detection of these injuries after vaginal delivery, which allows a timely and better treatment with less complications, with endoanal sonography offering the best detection rates so far.
\end{abstract}

Keywords: Anal injuries, Postpartum, Ultrasound.

How to cite this article: Grigoriadis T, Mylona SC, Giannoulis G, Athanasiou S, Antsaklis A. Sonographic Evaluation of Obstetric Anal Injuries. Donald School J Ultrasound Obstet Gynecol 2015;9(3):266-274.

\section{Source of support: Nil}

Conflict of interest: None

\section{INTRODUCTION}

Obstetric anal sphincter injuries (OASIS) represent a group of perineal tears with a reported incidence varying between 1 and $18 \%^{1-7}$ of the vaginal deliveries. Obstetric anal sphincter injuries include a wide spectrum of defects, ranging from a superficial involvement of the anal sphincter to tears that extend to both the anal sphincter and the anorectal epithelium. ${ }^{8}$ Obstetric anal sphincter injuries are associated with both short-term consequences, such as hemorrhage, wound breakdown, abscess formation, perineal pain and long-term complications which may include rectovaginal fistulae

\footnotetext{
1-5 Department of Urogynecology, 1st Department of Obstetrics and Gynecology, Alexandra Maternity Hospital, University of Athens, Greece

Corresponding Author: Themos Grigoriadis, Urogynecology Unit, 1st Department of Obstetrics and Gynecology, University of Athens, Alexandra Hospital, Lourou 1 Str, Athens, 11528, Greece e-mail: tgregos@yahoo.com
}

or anal incontinence., ${ }^{9,10}$ Anal sphincter damage after childbirth is considered the most important etiological factor in the pathogenesis of anal incontinence in women. ${ }^{11}$ Up to $53 \%$ of young healthy women, who sustained OASIS, may develop anal incontinence despite having these lacerations diagnosed and repaired at delivery. ${ }^{12-15}$

These sequelae may have a devastating effect on the women's physical and emotional well-being leading to social exclusion, loss of self-confidence and impairment of their quality of life. ${ }^{16}$ Furthermore, the occurrence of OASIS has legal implications; medical litigation is becoming increasingly common in women with OASIS and fecal incontinence. ${ }^{17}$ The fear of these injuries and of their consequences may have had a significant contribution to the almost $60 \%$ increase in cesarean deliveries in the USA. ${ }^{18}$ For the above mentioned reasons a prompt diagnosis of OASIS following vaginal deliveries is crucial for the provision of appropriate care, management and future follow-up.

During the last two decades, the advent of endoanal ultrasonography (EAUS) allowed an accurate evaluation of the anal sphincter complex and has revolutionized the understanding of the pathophysiology of anal incontinence. Aim of this study is to review the current evidence on the methodology of ultrasonographic examination of the anal sphincter, the imaging of OASIS and the clinical implications of their sonographic evaluation.

\section{ANATOMY OF ANAL SPHINCTER}

The anal sphincter is composed of several cylindrical layers. The innermost layer is the subepithelium that seals off the anal canal (anal cushions)..$^{19}$ The next layer is the internal anal sphincter (IAS), which is a thickened continuation of the circular muscle layer of the rectum into the anal canal. ${ }^{20}$ The outermost layer is the striated muscle of the external anal sphincter (EAS), which is made up of voluntary muscle deriving from the levator ani and puborectalis muscle. ${ }^{21}$ Although EAS forms a cylinder of muscle that encompasses the IAS, EAS and IAS are distinct structures that are separated by the intersphincteric plane that consists of a fibromuscular layer, the 'conjoint' longitudinal coat and the intersphincteric space with its connective tissue components. The 'conjoint' longitudinal coat is a continuation of the longitudinal muscle of the bowel. ${ }^{22}$ Overall, five separate anatomical layers have 
been described, including: mucosa, submucosa, IAS, intersphincteric plane and EAS.

\section{CLASSIFICATION OF PERINEAL TEARS AND RISK FACTORS}

In 1999, Sultan introduced a descriptive classification of the perineal traumas which is based on the clinical examination of the perineum and the anal sphincter following delivery. ${ }^{23}$ First degree tears include lacerations of the vaginal epithelium or the perineal skin only, whilet the second degree tears include injuries involving the perineal muscles but not the anal sphincter. The third degree perineal tears involve injuries of the anal sphincter, whereas fourth degree tears involve both the anal sphincter and the anorectal epithelium. Sultan's classification is now widely accepted and has been used by various national and international scientific societies, such as the Royal College of Obstetricians and Gynaecologists $^{24}$ and the International Consultation on Incontinence ${ }^{25}$ (Table 1). Various studies identified a number of factors associated with an increased risk of occurrence of OASIS ${ }^{6,26-43}$ (Table 2).

\section{ULTRASONOGRAPHIC IMAGING OF ANAL SPHINCTER}

Endoanal ultrasonography was first described by Law and Bartram, ${ }^{44}$ in 1989, using a BandK type 1846 (Bruel\&Kjaer, Naerum, Denmark) ultrasonographic scanner with a $7 \mathrm{MHz}$ rotating endoprobe. Sultan et $\mathrm{al}^{45}$ initially validated the endosonographic anatomy of the

Table 1: Classification of perineal trauma ${ }^{23}$

\begin{tabular}{|c|c|}
\hline Type of tear & Definition \\
\hline First-degree & Injury to the perineal skin \\
\hline Second-degree & $\begin{array}{l}\text { Injury to the perineum involving the } \\
\text { perineal muscles, but not involving } \\
\text { the anal sphincter }\end{array}$ \\
\hline Third-degree & $\begin{array}{l}\text { Injury to the perineum involving the } \\
\text { anal sphincter complex: }\end{array}$ \\
\hline$(3 \mathrm{~A})$ & $<50 \%$ of the EAS thickness torn \\
\hline$(3 \mathrm{~B})$ & $>50 \%$ of the EAS thickness torn \\
\hline$(3 \mathrm{C})$ & Both the EAS and the IAS torn \\
\hline Fourth-degree & $\begin{array}{l}\text { Injury to the perineum involving the } \\
\text { anal sphincter complex (both the } \\
\text { EAS and the IAS) and anal epithelium }\end{array}$ \\
\hline \multicolumn{2}{|c|}{$\begin{array}{l}\text { Table 2: Risk factors associated with increased } \\
\text { occurrence of OASIS }\end{array}$} \\
\hline Birth weight over $4 \mathrm{~kg}$ & Second stage longer than 1 hour \\
\hline $\begin{array}{l}\text { Persistent occipito- } \\
\text { posterior position }\end{array}$ & Shoulder dystocia \\
\hline Nulliparity & Midline episiotomy \\
\hline Induction of labor & Forceps delivery \\
\hline Epidural analgesia & \\
\hline
\end{tabular}

anal sphincter complexby in vivo and in vitro correlation with anatomical dissections of anorectal specimens and later demonstrated the normal sonographic anal sphincter anatomy and the differences between males and females. ${ }^{46}$

The classic approach of EAUS is by using a 2D 7 to $10 \mathrm{MHz}$ rotating endoprobe (focal range $5-45 \mathrm{~mm}$ ), 12 to $17 \mathrm{~mm}$ in diameter, filled with degassed water, which allows a $360^{\circ}$ axial view of the anal canal. The patient lies in the left lateral or prone/lithotomy position, ${ }^{47,48}$ although the latter is generally preferred for the acquisition of optimal images and also to avoid deformation of the anterior anatomic elements. ${ }^{48}$ Digital anal examination prior to the sonographic examination is recommended, to obtain information on the anatomy of the anal canal and to exclude the presence of scars or stenotic lesions. ${ }^{48}$ The endoscopic probe, covered with a lubricated condom is inserted about $6 \mathrm{~cm}$ into the rectum and as the probe is withdrawn down the anal canal, images of the puborectalis muscle, the anal mucosa and submucosa, IAS, longitudinal and EAS become visible. Two-dimensional endoanal ultrasonography generates cross-sectional images in the axial plane only.

More recently, 3D-EAUS has been introduced. Images are obtained using the same probe that is utilized for 2D imaging. It is mounted onto a hand-held mechanical rig which moves the probe in the caudal direction at a constant velocity when in use and constructs a 3D image. ${ }^{49}$ Three-dimensional endoanal ultrasonography creates volumetric images which can be extrapolated to multiplanar (coronal, sagittal and axial) or tomographic slicing images ${ }^{50-52}$ (Fig. 1). The use of appropriate software allows the analysis of stored 3D volumes for a later review, keeping the duration of the examination short. ${ }^{53}$

In 1999, Gold et $\mathrm{al}^{54}$ defined four sonographically distinct levels for the assessment of the anal canal in the axial plane $\mathrm{e}^{53,55}$ (Fig. 2).

1. Puborectalis level: Identified as a U-shaped hyperechoic band situated just proximal to the formation of the EAS (Fig. 3).

2. Proximal (high) anal canal: At most cranial level of the EAS where EAS, longitudinal muscle and IAS are visible.

3. Middle anal canal: The level where the EAS forms a complete circular region (ring) around the IAS. The lower end is identified at the distal end of the IAS.

4. Subcutaneous (low) anal canal: The level immediately below the termination of the IAS, where only the EAS is seen.

The different levels of the normal anal canal appear as hypoechoic or hyperechoic layers ${ }^{49}$ (Fig. 4). Starting from inside and moving outwards the first layer is hyperechoic and corresponds to the interface of the transducer with the anal mucosal surface. The second layer is moderately 


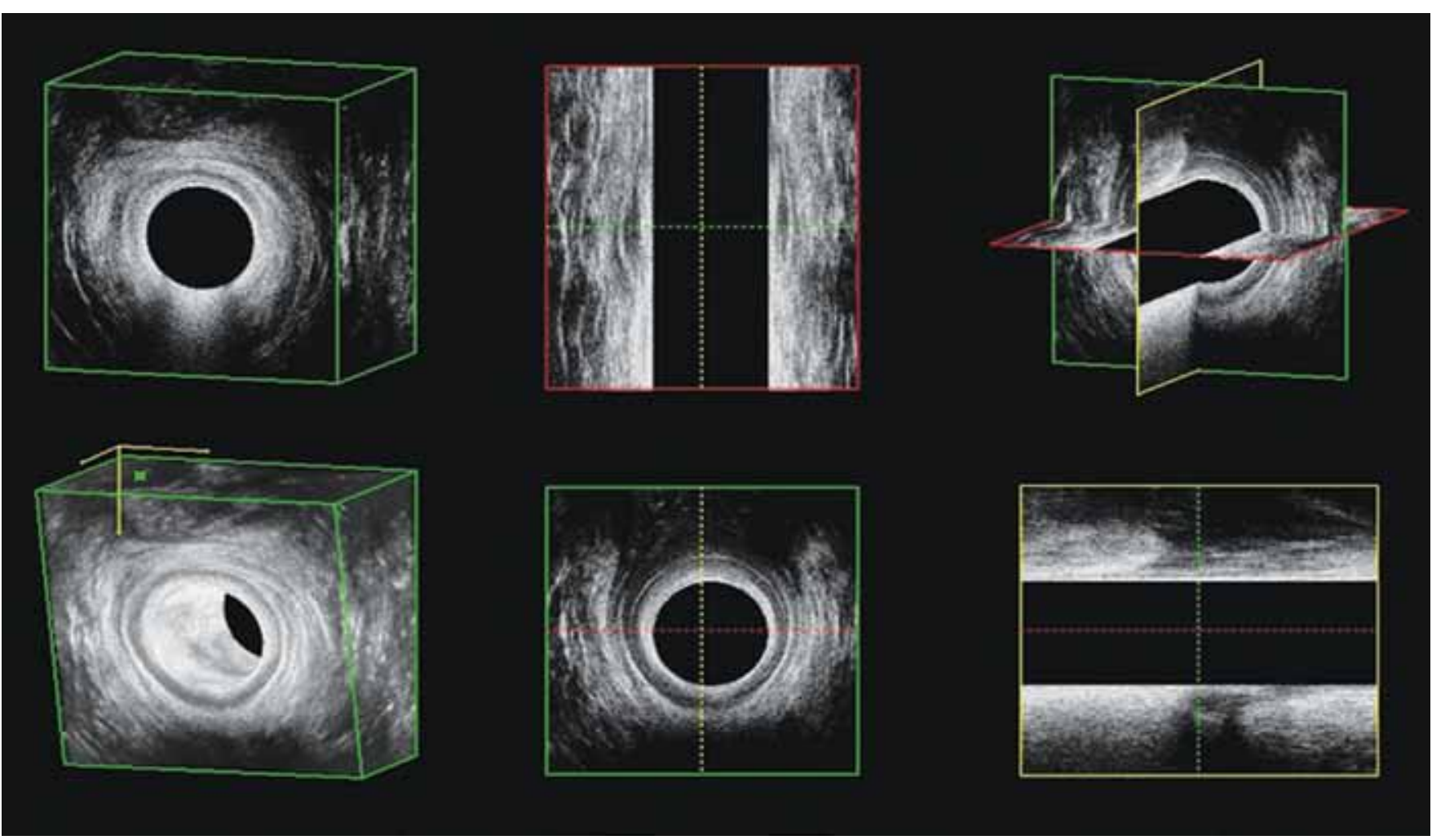

Fig. 1: Three-dimensional-EAUS allowing multiplanar imaging

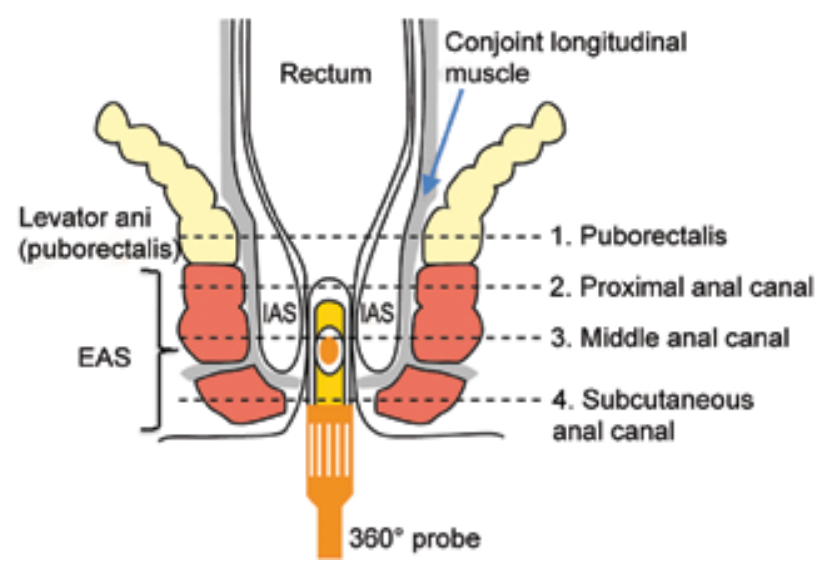

Fig. 2: Levels of sonographic assessment of the anal canal ${ }^{49}$

reflective and represents the submucosa which is composed of connective tissue and smooth muscle. The third layer corresponds to the IAS which is hypoechoic, giving an impression of a ring-like hypoechoic formation around the submucosa. It does not extend inferiorly beyond the subcutaneous external sphincter. The fourth layer is hyperechoic and represents the longitudinal muscle. The longitudinal muscle layer is not always distinguishable from the external sphincter, and has been reported as being seen in only $40 \%$ of females as they are of similar echogenicity and, therefore, indistinguishable. The fifth layer corresponds to the EAS which usually appears hyperechoic and has a heterogeneous appearance due to variations in the orientation of some fibers of the EAS.

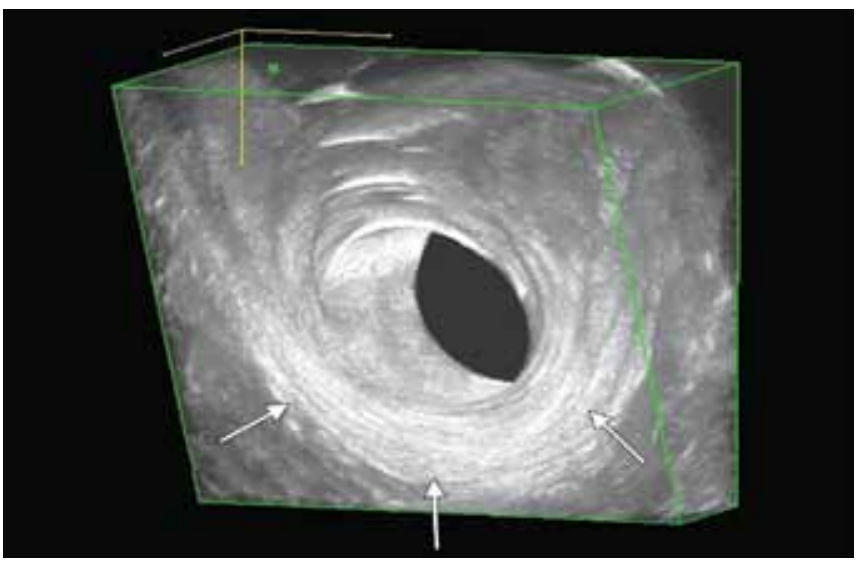

Fig. 3: Three-dimensional-endoanal ultrasonography demonstrating the ' $U$ '-shaped puborectalis muscle (arrows)

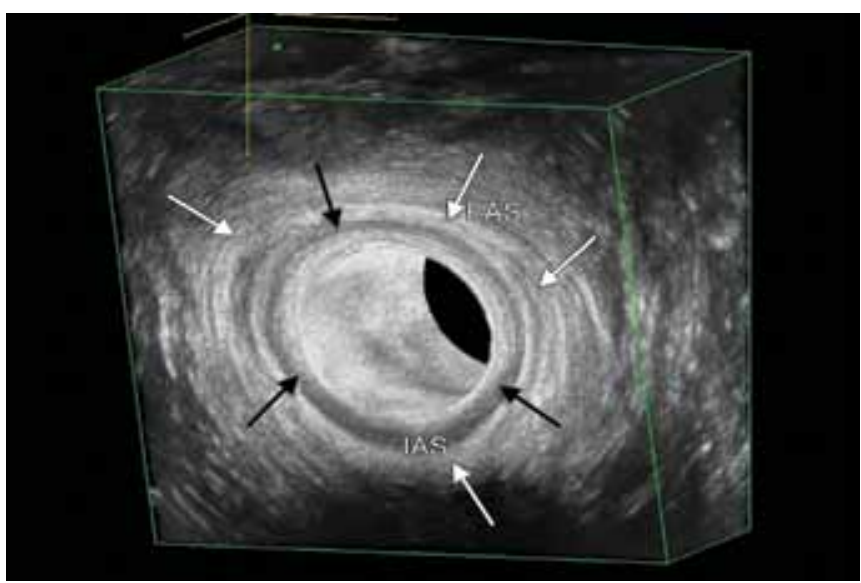

Fig. 4: Three-dimensional-endoanal ultrasound of the anal canal showing the hypoechoic IAS (white arrows) and the hyperechoic EAS (black arrows) 


\section{ENDOANAL ULTRASONOGRAPHY IMAGING OF OASIS}

The anal sphincter defects, when evaluated with EAUS, have specific sonographic images. A laceration of the IAS can be noted as lack of continuity in the concentric hypoechogenic ring which runs along the submucosal level at the middle or proximal anal canal. ${ }^{53}$ The presence of an incomplete circular pattern in the anterior compartment of EAS before the end of the IAS represents an EAS trauma at the level of the middle anal canal. ${ }^{53}$ It should be noted that in $98 \%$ of women the EAS is shorter anteriorly compared to the posterior part and therefore any discontinuity of the EAS anteriorly at the proximal level should not be confused with an injury of the EAS. ${ }^{56}$ Starck et $\mathrm{al}^{57}$ have shown that the mean length of the anterior part of the EAS in nulliparous women is $7 \mathrm{~mm}$ less than is that of the posterior part. At the level of distal anal canal, any disruption of the continuity in the concentric ring of hyper or mixed echogenicity that represents the EAS, also describes a laceration of the EAS. ${ }^{53}$

Starck et $\mathrm{al}^{58}$ devised a scoring system using 2D-EAUS images, with assessments every $5 \mathrm{~mm}$ from the puborectalis muscle to the distal end of the anal canal, evaluating length, depth and radial extent of defects to the IAS and EAS (Table 3). Scores range from 0 (no defect) to 16 (maximal defect).

Recently, Norderval et $\mathrm{al}^{59}$ reported a simplified system for analyzing defects, with fewer categories compared with the Starck score and not recording partial defects of the IAS. Using this system, the maximal score of 7 denotes defects in both the EAS and the IAS exceeding $90^{\circ}$ in the axial plane and involving more than half of the length of each sphincter. Both scoring systems seem equally reproducible with good intraobserver and interobserver agreement in classifying. ${ }^{59}$

\section{ROLE OF EAUS IN EVALUATING OASIS}

In 1993 Sultan et $\mathrm{l}^{60}$ found that up to $35 \%$ of primiparous women had sonographic evidence of obstetric traumas

Table 3: The Starck scoring system for endosonographic sphincter defects ${ }^{58}$

\begin{tabular}{|c|c|c|c|c|}
\hline Score & 0 & 1 & 2 & 3 \\
\hline \multicolumn{5}{|l|}{ External sphincter } \\
\hline Length of defect & None & $\begin{array}{l}\text { Half or } \\
\text { less }\end{array}$ & $\begin{array}{l}\text { More } \\
\text { than half }\end{array}$ & Whole \\
\hline Depth of defect & None & Partial & Total & - \\
\hline Size of defect & None & $>90^{\circ}$ & $91-180^{\circ}$ & $>180^{\circ}$ \\
\hline \multicolumn{5}{|l|}{ Internal sphincter } \\
\hline Length of defect & None & $\begin{array}{l}\text { Half or } \\
\text { less }\end{array}$ & $\begin{array}{l}\text { More } \\
\text { than half }\end{array}$ & Whole \\
\hline Depth of defect & None & Partial & Total & - \\
\hline Size of defect & None & $>90^{\circ}$ & $91-180^{\circ}$ & $>180^{\circ}$ \\
\hline
\end{tabular}

involving the sphincter muscles as opposed to a clinical diagnosis of OASIS of only $3 \%$. This observation was reinforced by subsequent endosonographic studies of the anal complex. ${ }^{61}$ Thus, EAUS performed several weeks after vaginal deliveries, detected higher rates of rupture, suggesting that some sphincter tears were not diagnosed by clinical examination alone at delivery. ${ }^{61}$ A few prospective studies reported that between 20 and $41 \%$ of women who delivered vaginally had sonographic evidence of anal sphincter injuries that were not diagnosed clinically. ${ }^{61}$ Such defects that are not visible at delivery but can be detected with ultrasound imaging of the anal sphincter immediately postpartum are considered 'occult' anal sphincter injuries. ${ }^{53}$

Undiagnosed or 'occult' OASIS is believed to be clinically relevant as some asymptomatic women with clinically undiagnosed anal sphincter injury seem to develop symptoms of fecal incontinence after a second vaginal delivery. ${ }^{62}$ Faltin et $\mathrm{al}^{63}$ found that women who were found to have 'occult' anal sphincter injuries had an increased risk of anal incontinence 3 months after delivery [odds ratio (OR) 8.8; 95\% CI 2.9, 26.5]. However, recent evidence suggests that most anal sphincter injuries previously classified as occult represent cases of clinically missed OASIS and that true occult anal sphincter injuries are rare. ${ }^{61}$ In a prospective trial ${ }^{64}$ where women after delivery were re-examined by a trained research fellow before suturing of the perineum, the detection rate of OASIS increased significantly from 11 to $24.5 \%$ suggesting that the genuine occult sphincter injuries are uncommon. The authors concluded that there is need for better and more focused training of staff at delivery suite to recognize OASIS. Similar results were found in a recent prospective observational study ${ }^{53}$ of primiparous women delivered vaginally, where $12 \%$ of women evaluated by 3-D EAUS were diagnosed with sphincter disruption compared to only $6.5 \%$ which were clinically diagnosed at delivery. The authors commented that these results do not imply that all primiparous women without clinical anal sphincter lacerations should undergo US examination postpartum and emphasis should be placed on careful examination of the rectovaginal wall and perineum in all women following delivery. Other studies also found that the accuracy of the clinical recognition of OASIS is depended on the training and the experience of the examiner ${ }^{61,64}$ reinforcing the notion that an appropriate training of health providers is essential to reduce the likelihood of a clinically missed OASIS. ${ }^{64,65}$

\section{ENDOANAL ULTRASONOGRAPHY AFTER PRIMARY REPAIR OF OASIS}

The value of EAUS has been studied for the evaluation of women who underwent primary repair of OASIS. In the 
literature, there are studies reporting a high frequency of endosonographic sphincter defects, as high as $90 \%$ among the women who underwent primary suture of sphincter tears. ${ }^{58}$ Interestingly, Starck et $\mathrm{al}^{58}$ found that the extent of the endosonographic defects 2 to 7 days after delivery and primary repair seems to be determined mainly by the surgical experience of the doctor performing the repair, and not by the clinical degree of the tear. In another study, Starck et al ${ }^{66}$ assessed women who had suffered OASIS with EAUS and anal manometry 1 week, 3 months and 1 year after primary suture and their subjective symptoms at 1 and 4 years after delivery. Endosonographic sphincter defect score 1 week after primary repair was positively correlated with the risk of reported anal incontinence at 4 years. The authors concluded that it might be valuable to check the result of primary repair with anal endosonography immediately after the repair and to re-suture if a large defect is still seen.

\section{ALTERNATIVE TECHNIQUES FOR IMAGING OF THE ANAL SPHINCTER}

Although EAUS is considered the gold standard technique for the assessment of the anal sphincter complex, ${ }^{67}$ the availability of both the required equipment and the trained personnel is limited. Furthermore, EAUS is an invasive technique which might cause discomfort to the patient particularly when performed in the immediate postpartum period. Additionally, the insertion of the ultrasound probe into the anal canal may distort the normal anatomy precluding dynamic evaluation of the anal sphincter and mucosa on sphincter contraction which seems to enhance the definition of muscular defects. ${ }^{68}$

\section{ENDOVAGINAL ULTRASONOGRAPHY}

In 1994 Sultan et al ${ }^{69}$ described a transvaginal technique for the assessment of the anal canal. A B\&K rotating endoprobe fitted with a $7 \mathrm{MHz}$ transducer was inserted $3 \mathrm{~cm}$ into the vagina and was gradually withdrawed to visualize the puborectalis muscle, EAS, IAS, anal submucosa and anal cushions. Later Kammerer-Doak et $\mathrm{al}^{70}$ employed a simple technique to image the anal sphincter by means of a transvaginal ultrasound probe. They were able to detect separated anal sphincters in $40 \%$ of women with obstetric lacerations. Timor-Tritsch et $\mathrm{al}^{71}$ described a similar technique by using a common 5 to $8 \mathrm{MHz}$ transvaginal probe which was placed in the posterior fourchette, first in the transverse and then in the longitudinal fashion. The authors reported that the images obtained using this imaging modality show the sphincter muscle anatomy as well as other possible pathology. With this technique a new sonographic sign was described: the 'mucosal star' which is seen on transverse sections, created by the normal, empty lower rectal mucosal folds and the constricted anus. They concluded that due to its simplicity and availability Endovaginal ultrasonography (EVUS) should be used whenever the anatomical integrity of the anal sphincter mechanism is questioned.

More recently, Olsen et $\mathrm{al}^{72}$ reported that the use of 3D-EVUS allows imaging of the anal canal and its neighboring structures without the distortion caused by a straight ultrasound rod inserted in the anal canal as when performing EAUS. In addition, 3D-EVUS allows a real time functional assessment of the anal canal during voluntary squeeze, adding thus important insight into the mechanisms of continence and its disorders. However, among the limitations of this technique is the difficult interpretation of the images which have been reported in up to $24 \%$ of the cases, requiring more experienced operators and the increased possibility of failure in obtaining clear images of the full length of the anal canal, mainly due to inadequate acoustic contact within the vagina. ${ }^{73,74}$ Furthermore TVUS demonstrated limited precision in revealing lateral tears probably as a result of the lack of anal distention which keeps the muscular fibers relaxed hiding the defect through overlapping. ${ }^{74}$

\section{TRANSPERINEAL ULTRASONOGRAPHY}

The technique of transperineal ultrasonography (TPUS) of the anal canal (exoanal ultrasound) was first described in 1997 by Peschers et al, ${ }^{75}$ using a $5 \mathrm{MHz}$ convex probe to a group of 68 females ( 25 with fecal incontinence, 11 asymptomatic nulliparous and 32 asymptomatic parous females). In this study, all the layers of the anal sphincter complex were visualized as described by EAUS and the detected sphincter defects were confirmed at sphincter reconstructive surgery which was performed in five patients. Transperineal ultrasonography is usually performed with the patient placed in the dorsal lithotomy position by applying an external convex transducer on the perineum between the mons pubis and the anal sphincter. ${ }^{76}$ Although variations of the technique have been described, ${ }^{77}$ the original approach by Peschers et $\mathrm{al}^{75}$ is widely and increasingly used to evaluate the anal sphincters. $^{78}$

Yagel and Valsky ${ }^{79}$ first introduced the 3D-TPUS for the assessment of the anal sphincter, using a 5 to $9 \mathrm{MHz}$ $3 \mathrm{D}$ vaginal probe, placed in the area of the fourchette. However, the authors did not establish a definition for anal sphincter defects on tomographic imaging. In a group of 139 primiparous females, Yagel and Valsky ${ }^{79}$ found that using 3D-TPUS 7.9\% of women had occult damage to the anal sphincter. These authors described the 'half moon sign' as a thinning of the IAS in the area of damage and thickening on the opposite side, as well as an abnormal appearance of the 'star sign' of the mucosal 
folds in almost half of the patients, as signs indicative of sphincter damage.

More recently DGuzmán et $\mathrm{l}^{78}$ studied retrospectively women at 35 to 37 weeks of gestation and 3 to 6 months postpartum. In this study, a translabial 4D US examination using a 8 to $4 \mathrm{MHz}$ curved array volume transducer. Twenty-eight percent of those delivered vaginally had sonographic evidence of significant EAS defects of which $87 \%$ were not diagnosed clinically. The incidence of clinically undetected OASIS was comparable to those reported in the literature using EAUS. Transperineal ultrasonography is considered more accessible to obstetricians than EAUS due to the wider availability of conventional convex abdominal transducers and is well-tolerated by the patients, since the probe used for the examination is applied externally. ${ }^{54}$ However, with TPUS, excessive pressure applied by the transducer on the perineum or an inappropriate angle of incidence of the ultrasound beam to the anal canal may result in erroneous results. ${ }^{80}$ Compared with 3D-EAUS, 3D-TPUS is unable to identify clearly the conjoined longitudinal layer and the superficial transverse perineii muscle or to measure the anterior longitudinal length of the EAS, but has the advantage of demonstrating not just the IAS and EAS but also the perineal body and the entire sling of the puborectalis muscle. ${ }^{80}$

\section{ENDOANAL ULTRASONOGRAPHY FOR POST- PARTUM EVALUATION OF OASIS AND FUTURE PREGNANCY}

The management of a subsequent delivery following previous OASIS remains controversial due to lack of objective and subjective evidence regarding outcome and quality of life as assessed with validated measurement tools. ${ }^{81}$ The main issues to be considered in such cases are the risk of OASIS recurrence and the risk of developing or worsening of anal incontinence.

In the literature, there is evidence that 17 to $25 \%$ of women who had sustained a $3 \mathrm{~d}$ degree OASIS and have a subsequent vaginal delivery, experience an aggravation of anal incontinence symptoms. ${ }^{82-86}$ Fynes et al ${ }^{84}$ demonstrated that $75 \%$ of women with objective anal sphincter compromise but no anal incontinence after the index delivery, developed de novo anal incontinence compared to $5 \%$ without evidence of anal sphincter compromise. However, a recent prospective study ${ }^{81}$ revealed that women who sustain OASIS have a $7 \%$ risk of recurrence and women who do not have substantial compromise of anal sphincter function can deliver vaginally without risking significant deterioration in anal sphincter morphology and function or quality of life. The exact 'criteria of security' for vaginal delivery after previous obstetric sphincter trauma are still the subject of debate and remain to be determined. ${ }^{87}$

Mahony et $\mathrm{al}^{86}$ studied prospectively 52 women who had forceps assisted and normal vaginal deliveries antenatally and again at 12 weeks after second delivery using a standardized bowel function questionnaire, EAUS, and anal manometry. The presence of an anal sphincter defect defined by EAUS was associated with a minor but not significant symptomatic deterioration after second vaginal delivery. More than one-quarter of women (10/38) with an anal sphincter defect identified by EAUS experienced minor symptomatic alteration ( $\leq 3$ point increase in incontinence score) after second vaginal delivery compared with $14 \%(2 / 14)$ of women with a normal EAUS, but this difference was not significant. Recently, Daly et $\mathrm{al}^{88}$ prospectively evaluated 381 antenatal women with a history of OASIS $(38.4 \pm 22$ months following the index OASIS). All women routinely had a St Mark's incontinence score (SMIS), EAUS and anal manometry. In their practice a vaginal delivery is recommended to those women with minimal symptoms, an intact sphincter or a external sphincter scar of less than $30^{\circ}$ and a squeeze incremental pressure of more than $20 \mathrm{~mm} \mathrm{Hg}$, whereas a cesarean section is recommended to all other women. Using these criteria 321 (84.3\%) women were recommended to have a vaginal delivery, with 19 $(7.6 \%)$ recurrent OASIS. Their results confirmed that the majority of women with minimal symptoms, an intact or minimally scarred anal sphincter with an incremental squeeze pressure of $>20 \mathrm{~mm} \mathrm{Hg}$ can achieve a vaginal delivery without clinical deterioration in anorectal symptoms and lifestyle at 3 months postpartum.

Concluding, EAUS can provide useful information for the management of women with a history of OASIS. Ultrasound may contribute establishing the sonographic appearance of damage early after repair, monitoring the progress of healing process over time in the anal area, and comparing the sonographic appearance with any degree of incontinence symptoms. By providing this information, ultrasound assessment of the anal sphincter can contribute to the antenatal counseling of women who have sustained OASIS serving probably even as a screening examination for high risk patients prior to subsequent trial of labor or elective cesarean delivery. ${ }^{87}$

\section{CONCLUSION}

Currently, EAUS is considered the gold standard investigation in the assessment of anal sphincter integrity providing an assessment of high precision and accuracy. ${ }^{55,67}$ Furthermore, EAUS has been proved to be equivalent to magnetic resonance imaging and superior to electromyographic sphincter mapping in 
detecting sphincter defects ${ }^{67}$ However, limitations of the EAUS, either 2D or 3D, is the need for a specialized, expensive equipment and access to staff trained in endoanal ultrasound on the labor ward which may not be available in a general obstetrics and gynecology unit. This technique may also prove to be uncomfortable for the patient and there is a small risk for disruption of the anal sphincter structure during the examination. The need to use more common transducers which are widely available to the gynecological wards led to the introduction and development of other techniques, such us the EVUS and TPUS. Advantages of such routes include availability of low cost transducers, absence of distortion of the anal canal caused by the EAUS and recently the assessment of real time functional studies. Future studies should focus on the predictive value of both EVUS and TPUS as compared with EAUS in the detection of sphincter defects. $^{55}$

\section{REFERENCES}

1. Räisänen S, Vehviläinen-Julkunen K, Gissler M, HeinonenS. Up to seven-fold inter-hospital differences in obstetric anal sphincter injury rates-a birth register-based study in Finland. BMC Res Notes 2010;3(1):345.

2. Laine $\mathrm{K}$, Gissler M, Pirhonen J. Changing incidence of anal sphincter tears in four Nordic countries through the last decades. Eur J Obstet Gynecol Reprod Biol 2009;146(1):71-75.

3. Pirhonen JP, Grenman SE, Haadem K, Gudmundsson S, Lindqvist P, Siihola S, Erkkola RU, Marsal K. Frequency of anal sphincter rupture at delivery in Sweden and Finlandresult of difference in manual help to the baby's head. Acta Obstet Gynecol Scand 1998;77(10):974-977.

4. Prager M, Andersson KL, Stephansson O, Marchionni M, Marions L. The incidence of obstetric anal sphincter rupture in primiparous women: a comparison between two European delivery settings. Acta Obstet Gynecol Scand 2008;87(2): 209-215.

5. Baghestan E, Irgens LM, Bordahl PE, Rasmussen S. Trends in risk factors for obstetric anal sphincter injuries in Norway. Obstet Gynecol 2010;116(1):25-34.

6. Handa VL, Danielsen BH, Gilbert WM. Obstetric anal sphincter lacerations. Obstet Gynecol 2001;98(2):225-230.

7. Fenner DE, Genberg B, Brahma P, Marek L, DeLancey JO. Fecal and urinary incontinence after vaginal delivery with anal sphincter disruption in an obstetrics unit in the United States. Am J Obstet Gynecol 2003;189(6):1549-1550.

8. Roos AM, Thakar R, Sultan AH. Outcome of primary repair of obstetric anal sphincter injuries (OASIS): does the grade of tear matter? Ultrasound Obstet Gynecol 2010;36(3):368-374.

9. Thach TS. Methods of repair for obstetric anal sphincter injury: RHL commentary [Internet]. Geneva: World Health Organization. Available at: http://apps.who.int/rhl/pregnancy_ childbirth/childbirth/perineal_trauma/ttcom2/en/

10. Sultan AH, Kamm MA, Hudson CN, Bartram CI. Third degree obstetric anal sphincter tears: risk factors and outcome of primary repair. BMJ 1994;308(6933):887-891.

11. Swash M. Faecal incontinence. BMJ 1993 Sep 11;307(6905): 636-637.
12. Haadem $\mathrm{K}$, Ohrlander S, Lingman G. Long-term ailments due to anal sphincter rupture caused by delivery - a hidden problem. Eur J Obstet Gynecol Reprod Biol 1988;27(1):27-32.

13. Haadem K, Dahlström JA, Lingman G. Anal sphincter function after delivery: a prospective study in women with sphincter rupture and controls. Eur J Obstet Gynecol Reprod Biol 1990;35(1):7-13.

14. Fitzpatrick M, Behan M, O'Connell PR, O'Herlihy C. A randomized clinical trial comparing primary overlap with approximation repair of third-degree obstetric tears. Am J Obstet Gynecol 2000;183(5):1220-1224.

15. Zetterström J, López A, Holmström B, Nilsson BY, Tisell A, Anzén B, Mellgren A. Obstetric sphincter tears and anal incontinence: an observational follow-up study. Acta Obstet Gynecol Scand 2003;82(10):921-928.

16. Perry S, Shaw C, McGrother C, Matthews RJ, Assassa RP, Dallosso H, Williams K, Brittain KR, Azam U, Clarke M, et al. Prevalence of faecal incontinence in adults aged 40 years or more living in the community. Gut 2002;50(4):480-484.

17. Vaizey CJ, Phillips RK. A twisted tale. Clin Risk 2005;11(2):53-56.

18. Hamilton, BE.; Martin, JA.; Ventura, SJ. Births: preliminary data for 2009 [Internet]. Available at: http://www.cdc.gov/ nchs/data/nvsr/nvsr60/nvsr60_02.pdf.

19. Gibbons CP, Read NW, Trowbridge EA, Akos K. Anal cushions. Lancet 1986;328(8497):42.

20. Raizada V, Mittal RK. Pelvic floor anatomy and applied physiology. Gastroenterol Clin North Am 2008 Sep;37(3): 493-509.

21. Santoro, Guilio A, Di Falco, G. Benign Anorectal Diseases: Diagnosis with Endoanal and Endorectal Ultrasound and New Treatment Options. 1st ed. Italy: Springer; 2006. 424 p.

22. Lunniss PJ, Phillips RK. Anatomy and function of the anal longitudinal muscle. Br J Surg 1992;79(9):882-884.

23. Sultan AH. Editorial: Obstetric perineal injury and anal incontinence. AVMA Med Legal J 1999;5(6):193-196.

24. Royal College of obstetricians and gynaecologists (RCOG). Management of third- and fourth- degree perineal tears following vaginal delivery [Internet]. London; RCOG Press, 2007. Available at: https://www.rcog.org.uk/globalassets/ documents/guidelines/gtg-29.pdf

25. Norton, C.; Christiansen, J.; Butler, U., et al. Anal incontinence. In: Abrams, P.; Cardozo, L.; Khoury, S., et al., editors. Incontinence. 2nd ed. Plymouth: Health Publication Ltd; 2002. p. 985-1044.

26. Buekens $P$, Lagasse R, Dramaix M, Wollast E. Episiotomy and third degree tears. Br J Obstet Gynaecol 1985;92(8):820-823.

27. Anthony S, Buitendijk SE, Zondervan KT, van Rijssel EJ, Verkerk PH. Episiotomies and the occurrence of severe perineal lacerations. Br J Obstet Gynaecol 1994;101(12):1064-1067.

28. Poen AC, Felt-Bersma RJ, Dekker GA, Deville W, Cuesta MA, Meuwissen SG. Third degree obstetric perineal tears: risk factors and the preventative role of mediolateral episiotomy. Br J Obstet Gynaecol 1997;104(5):563-566.

29. Donnelly V, Fynes M, Campbell D, Johnson H, O'Connell R, O'Herlihy C. Obstetric events leading to anal sphincter damage. Obstet Gynecol 1998;92(6):955-961.

30. Poen AC, Felt-Bersma RJF, Strijers RL, Dekker GA, Cuesta MA, Meuwissen SG. Third degree obstetric perineal tear: long-term clinical and functional results after primary repair. Br J Surg 1998;85(10):1433-1438.

31. Gjessing H, Backe B, Sahlin Y. Third degree obstetric tears: outcome after primary repair. Acta Obstet Gynecol Scand 1998;77(7):736-740. 
32. Wood J, Amos L, Rieger N. Third degree anal sphincter tears: risk factors and outcome. Aust NZ J Obstet Gynaecol 1998; 38(4):414-417.

33. Sultan AH, Monga AK, Kumar D, Stanton SL. Primary repair of obstetric anal sphincter rupture using the overlap technique. Br J Obstet Gynaecol 1999;106(4):318-323.

34. Samuelsson E, Ladfors L, Wennerholm UB, Gareberg B, Nyberg K, Hagberg H. Anal sphincter tears: prospective study of obstetric risk factors. Br J Obstet Gynaecol 2000; 107(7):926-931.

35. Eason E, Labrecque M, Wells G, Feldman P. Preventing perineal trauma during childbirth: A systematic review. Obstet Gynecol 2000;95(3):464-471.

36. Jander C, Lyrenas S. Third \& fourth degree perineal tears: predictor factors in a referral hospital. Acta Obstet Gynecol Scand 2001;80(3):229-234.

37. de Leeuw JW, Sruijk PC, Vierhout ME, Wallenburg HC. Risk factors for third degree perineal ruptures during delivery. Br J Obstet Gynaecol 2001;108(4):383-387.

38. Fitzpatrick M, McQuillan K, O'Herlihy C. Influence of persistent occiput posterior position on delivery outcome. Obstet Gynecol 2001;98(6):1027-1031.

39. Bodner-Adler B, Bodner K, Kaider A, Wagenbichler P, Leodolter S, Husslein P, Mayerhofer K. Risk factors for third degree perineal tears in a vaginal delivery with an analysis of episiotomy types. J Reprod Med 2001;46(8):752-756.

40. Richter HE, Brumfield CG, Cliver SP, Burgio KL, Neely CL, Varner RE. Risk factors associated with anal sphincter tear: a comparison of primiparous vaginal births after caesarean deliveries, and patients with previous vaginal delivery. Am J Obstet Gynecol 2002;187(5):1194-1198.

41. Fitzpatrick M, Harkin R, McQuillan K, O'Brien C, O'Connell $\mathrm{PR}, \mathrm{O}^{\prime}$ Herlihy C. A randomised controlled trial comparing the effects of delayed versus immediate pushing with epidural on mode of delivery and faecal continence. BJOG 2002;109(12):1359-1365.

42. Christiansen LM, Bovbjerg VE, McDavitt EC, Hullfish KL. Risk factors for perineal injury during delivery. Am J Obstet Gynecol 2003;189(1):255-260.

43. McLeod NL, Gilmour DT, Joseph KS, Farrell SA, Luther ER. Trends in major risk factors for anal sphincter lacerations: a 10-year study. J Obstet Gynecol Can 2003;25(7):586-593.

44. Law PJ, Bartram CI. Anal endosonography: technique and normal anatomy. Gastrointest Radiol 1989;14(4):349-353.

45. Sultan AH, Nicholls RJ, Kamm MA, Hudson CN, Beynon J, Bartram CI. Anal endosonography and correlation with in vitro and in vivo anatomy. Br J Surg 1993;80(4):508-511.

46. Sultan AH, Kamm MA, Talbot IC, Nicholls RJ, Bartram CI. Anal endosonography for identifying external sphincter defects confirmed histologically. Br J Surg 1994;81(3):463-465.

47. Frudinger A, Bartram CI, Halligan S, Kamm M. Examination techniques for endosonography of the anal canal. Abdom Imaging 1998;23(3):301-303.

48. Barisic G, Krivokapic Z, Markovic V, Saranovic D, Kalezic V, Sekulic A. Endorectal ultrasound (ERUS) in pelvic disorders. Acta Chir Iugosl 2006;53(2):117-120.

49. Thakar R, Sultan AH. Anal endosonography and its role in assessing the incontinent patient. Best Pract Res Clin Obstet Gynaecol 2004 Feb;18(1):157-173.

50. Gold DM, Bartram CI, Halligan S, Humphries KN, Kamm MA, Kmiot WA. Three-dimensional endoanalsonography in assessing anal canal injury. Br J Surg 1999;86(3):365-370.
51. Williams AB, Bartram CI, Halligan S, Spencer JA, Nicholls $\mathrm{RJ}, \mathrm{Kmiot}$ WA. Anal sphincter damage after vaginal delivery using three-dimensional endosonography. Obstet Gynecol 2001;97(5 pt 1):770-775.

52. Williams AB, Bartram CI, Halligan S, Marshall MM, Spencer JA, Nicholls RJ, Kmiot WA. Alteration of anal sphincter morphology following vaginal delivery revealed by multiplanar anal endosonography. BJOG 2002;109(8):942-946.

53. Corton MM, McIntire DD, Twickler DM, Atnip S, Schaffer JI, Leveno KJ. Endoanal ultrasound for detection of sphincter defects following childbirth. Int Urogynecol J 2013 Apr; 24(4):627-635.

54. Gold DM, Halligan S, Kmiot WA, Bartram CI. Intraobserver and interobserver agreement in anal endosonography. Br J Surg 1999;86(3):371-375.

55. Abdool Z, Sultan AH, Thakar R. Ultrasound imaging of the anal sphincter complex: a review. Br J Radiol 2012 Jul;85(1015):865-875.

56. Bollard RC, Gardiner A, Lindow S, Phillips K, Duthie GS. Normal female anal sphincter: difficulties in interpretation explained. Dis Colon Rectum 2002;45(2):171-175.

57. Starck M, Bohe M, Fortling B, Valentin L. Endosonography of the anal sphincter in women of different ages and parity. Ultrasound Obstet Gynecol 2005;25(2):169-176.

58. Starck M, Bohe M, Valentin L. Results of endosonographic imaging of the anal sphincter 2-7 days after primary repair of third- or fourth-degree obstetric sphincter tears. Ultrasound Obstet Gynecol 2003 Dec;22(6):609-615.

59. Norderval S, Dehli T, Vonen B. Three-dimensional endoanal ultrasonography: intraobserver and interobserver agreement using scoring systems for classification of anal sphincter defects. Ultrasound Obstet Gynecol 2009;33(3):337-343.

60. Sultan AH, Kamm MA, Hudson CN, Thomas JM, Bartram CI. Anal-sphincter disruption during vaginal delivery. N Engl J Med 1993 Dec 23;329(26):1905-1911.

61. Andrews V, Sultan AH, Thakar R, Jones PW. Occult anal sphincter injuries - myth or reality? Br J Obste Gynaecol 2006;113(2):195-200.

62. Fynes M, Donnelly V, Behan M, O'Connell P, O'Herlihy C. Effect of second vaginal delivery on anorectal physiology and faecal continence: a prospective study. The Lancet 1999;345(9183):983-986.

63. Faltin DL, Boulvain M, Irion O, Bretones S, Stan C, Weil A. Diagnosis of anal sphincter tears by postpartum endosonography to predict fecal incontinence. Obstet Gynecol 2000 May;95(5):643-647.

64. Groom KM, Paterson-Brown S. Can we improve the diagnosis of third degree tears? Eur J Obstet Gynecol Reprod Biol 2002;101(1):19-21.

65. Sultan AH, Kamm MA, Hudson CN. Obstetric perineal trauma: an audit of training. J Obstet Gynaecol 1995;15(1): 19-23.

66. Starck M, Bohe M, Valentin L. The extent of endosonographic anal sphincter defects after primary repair of obstetric sphincter tears increases over time and is related to anal incontinence. Ultrasound Obstet Gynecol 2006 Feb;27(2): 188-197.

67. Haylen BT, de Ridder D, Freeman RM, Swift SE, Berghmans B, Lee J, Monga A, Petri E, Rizk DE, Sand PK, etal. An International Urogynecological Association (IUGA)/International Continence Society (ICS) joint report on the terminology 
for female pelvic floor dysfunction. Int Urogynecol J 2010 Jan;21(1):5-26.

68. Steensma A, Burger C, Schouten W. Is dynamic investigation of the anal sphincter complex useful for assessment of the anal sphincter complex? Ultrasound Obstet Gynecol 2008; 32(3):397.

69. Sultan AH, Loder PB, Bartram C, Kamm MA, Hudson $\mathrm{CN}$. Vaginal endosonography: a new technique to image the undisturbed anal sphincter. Dis Colon Rectum 1994; 37(12):1296-1299.

70. Kammerer-Doak DN, Wesol AB, Rogers RG, Dominguez $\mathrm{CE}$, Dorin $\mathrm{MH}$. A prospective cohort study of women after primary repair of obstetric anal sphincter laceration. Am J Obstet Gynecol 1999;181(6):1317-1322.

71. Timor-Tritsch IE, Monteagudo A, Smilen SW, Porges RF, Avizova E. Simple ultrasound evaluation of the anal sphincter in female patients using a transvaginal transducer. Ultrasound Obstet Gynecol 2005 Feb;25(2):177-183.

72. Olsen IP, Wilsgaard T, Kiserud T. Transvaginal threedimensional ultrasound: a method of studying anal anatomy and function. Ultrasound Obstet Gynecol 2011 Mar;37(3): 353-360.

73. Poen AC, Felt-Bersma RJ, Cuesta MA, Meuwissen GM. Vaginal endosonography of the anal sphincter complex is important in the assessment of faecal incontinence and perianal sepsis. Br J Surg 1998;85(3):359-363.

74. Ramírez JM, Aguilella V, Martínez M, Gracia JA. The utility of endovaginal sonography in the evaluation of fecal incontinence. Rev Esp Enferm Dig 2005;97(5):317-322.

75. Peschers UM, DeLancey JO, Schaer GN, Schuessler B. Exoanal ultrasound of the anal sphincter: normal anatomy and sphincter defects. Br J Obstet Gynaecol 1997Sep;104(9): 999-1003.

76. Abdool Z, Sultan AH, Thakar R. Ultrasound imaging of the anal sphincter complex: a review. Br J Radiol 2012 Jul;85(1015):865-875.

77. Valsky DV, Messing B, Petkova R, Savchev S, Rosenak D, Hochner-Celnikier D, Yagel S. Postpartum evaluation of the anal sphincter by transperineal three-dimensional ultrasound in primiparous females after vaginal delivery and following surgical repair of third-degree tears by the overlapping technique. Ultrasound Obstet Gynecol 2007; 29(2):195-204.

78. Guzmán Rojas RA, Shek KL, Langer SM, Dietz HP. The prevalence of anal sphincter injury in primiparous women. Ultrasound Obstet Gynecol 2013;42(4):461-466.

79. Yagel S, Valsky DV. Three-dimensional transperineal ultrasonography for evaluation of the anal sphincter complex: another dimension in understanding peripartum sphincter trauma. Ultrasound Obstet Gynecol 2006;27(2):119-123.

80. Santoro GA, Wieczorek AP, Dietz HP, Mellgren A, Sultan AH, Shobeiri SA, Stankiewicz A, Bartram C. State of the art: an integrated approach to pelvic floor ultrasonography. Ultrasound Obstet Gynecol 2011 Apr;37(4):381-396.

81. Scheer I, Thakar R, Sultan AH. Mode of delivery after previous obstetric anal sphincter injuries (OASIS) — a reappraisal? Int Urogynecol J Pelvic Floor Dysfunct 2009;20(9):1095-1101.

82. Bek KM, Laurberg S. Risks of anal incontinence from subsequent vaginal delivery after a complete obstetric anal sphincter tear. Br J Obstet Gynaecol 1992 Sep;99(9):724-726.

83. Tetzschner T, Sørensen M, Lose G, Christiansen J. Anal and urinary incontinence in women with obstetric anal sphincter rupture. Br J Obstet Gynaecol 1996 Oct;103(10):1034-1040.

84. Fynes M, Donnelly VS, O'Connell PR, O'Herlihy C. Cesarean delivery and anal sphincter injury. Obstet Gynecol 1998 Oct;92(4 Pt 1):496-500.

85. Poen AC, Felt-Bersma RJ, Strijers RL, Dekker GA, Cuesta MA, Meuwissen SG. Third-degree obstetric perineal tear: longterm clinical and functional results after primary repair. Br J Surg 1998 Oct;:85(10):1433-1438.

86. Mahony R, Behan M, O'Connell PR, O'Herlihy C. Effect of second vaginal delivery on anal function in patients at risk of occult anal sphincter injury after first forceps delivery. Dis Colon Rectum 2008;51(9):1361-1366.

87. Valsky DV, Cohen SM, Lipschuetz M, Hochner-Celnikier D, Yagel S. Three-dimensional transperineal ultrasound findings associated with anal incontinence after intrapartum sphincter tears in primiparous women. Ultrasound Obstet Gynecol 2012 Jan;39(1):83-90.

88. Daly J, Sultan A, Van Delft K, Thakar R. Outcome of childbirth after previous obstetric anal sphincter injury. Int Urogynecol J 2013;24 Suppl 1:S69-S70. 